\title{
MENAKAR INTEGRITAS ANAK SERIBU PULAU DI MALUKU UTARA
}

\section{FURTHER CHILDREN INTEGRITY IN NORTH MALUKU}

\author{
Baso Marannu \\ Balai Penelitian dan Pengembangan Agama Makassar \\ Jl. AP. Pettarani, No. 72 Makassar \\ Email: athobasomarannu70@gmail.com \\ Ali Hanafi \\ Sekolah Tinggi Ilmu Manajemen Publik Makassar \\ Jl. Maccini Tengah No. 50 Makassar \\ Email: alihanafilaupe@gmail.com
}

Naskah diterima tanggal 1 Mei 2018. Naskah direvisi tanggal 10 Mei 2018. Naskah disetujui tanggal 18 Mei 2018

\begin{abstract}
Abstrak
Penelitian integritas peserta didik merupakan program Nasional dari Pusat Penelitian dan Pengembangan Pendidikan Agama Badan Litbang dan Diklat Kementerian Agama, Penelitian ini dipicu dengan banyaknya kasus-kasus yang bermunculan saat ini mulai dari maraknya tawuran antar sekolah, merebaknya penggunaan narkoba di kalangan pelajar, berkembangannya pergaulan bebas. Selain itu banyak sekolah yang kurang memperhatikan perkembangan perilaku peserta didik terkait kejujuran akademik, contek menyontek saat ujian, konsisten dengan apa yang dikatakan, tanggung jawab terhadap tugas, dan membangun relasi dalam kehidupan keagamaan. Metode yang digunakan adalah kuantitatif dengan pendekatan survey, dilaksanakan di 34 provinsi dengan jumlah sampel 1158 sekolah dengan rincian 708 Sekolah Menengah Atas (SMA) di 164 kabupaten/kota dan 450 Madrasah Aliyah (MA) di 133 kabupaten/kota, khusus di Provinsi Maluku Utara sekolah yang dijadikan sampel sebanyak 14 sekolah yang diwakili masing-masing 10 peserta didik, sehingga jumlah sebanyak 140 peserta didik. Dengan menggunakan analisis deskriptif dari empat variabel yang telah ditetapkan yakni (1) kejujuran, (2) tanggung jawab, (3) toleransi dan (4) cinta tanah air. Pengukuran kejujuran secara keseluruhan ratarata persentasi kejujuran yang ditemukan pada responden masih rendah yakni 55\%. Dimensi tanggung jawab, hasilnya masih rendah yakni $62 \%$. Dimensi toleransi, rata-rata memberikan sikap integitas yang tinggi yakni 83\% atau tinggi dan Dimensi cinta tanah air, sebesar 93\% atau sangat tinggi.
\end{abstract}

Kata Kunci: integritas, kejujuran, tanggung jawab, toleransi, cinta tanah air.

\begin{abstract}
Student integrity research is a national program of Research and Development Center of Religious Education Research and Development Agency of Ministry of Religious Affairs, This research is triggered by the many cases that appear at this time ranging from the rise of brawl between schools, the spread of drug use among students, the development of promiscuity. In addition, many schools are less attention to the development of learners' behavior related to academic honesty, cheating cheek exam, consistent with what is said, responsibility to the task, and build relationships in religious life. The method used is quantitative survey approach, implemented in 34 provinces with total sample of 1158 schools with details of 708 Senior High Schools in 164 districts / cities and 450 Madrasah Aliyah (MA) in 133 districts / cities, specialized in North Maluku Province the sampled schools were 14 schools represented by 10 students each, bringing the total number of 140 students. By using descriptive analysis of four predetermined variables namely (1) honesty, (2) responsibility, (3) tolerance and (4) love the country. Measurement of honesty The overall average percentage of honesty found in respondents is still low at 55\%. Dimension of responsibility, the result is still low ie 62\%. Dimension of tolerance, on average gives high integrity attitude that is $83 \%$ or high and Dimension of love ground water, equal to $93 \%$ or very high
\end{abstract}

Keywords: integrity, honesty, responsibility, tolerance, love the fatherland. 


\section{PENDAHULUAN}

Sebuah pertanyaan sederhana, "pentingkah integritas peserta didik di zaman milenial saat ini?" di mana kecanggihan teknologi yang secara dini sulit mendeteksi apakah siswa benar-benar berintegritas, kecuali menggunakan teknologi itu sendiri. Merebaknya plagiat di kalangan pelajar dalam mengerjakan tugas-tugas sekolah dengan mengandalkan 'google', maraknya berita hoax antar peserta didik pada beberapa aplikasi media sosial, penipuan berdalih investasi berbasis teknologi hingga penyalahgunaan sistem belanja online yang sudah menjadi 'tren' di kalangan peserta didik. (Rianto, 2017:68). Kompleksitas gaya hidup masyarakat dengan kecepatan sistem informasi yang berkembang saat ini jika dikaitkan dengan integritas tentu menjadi persoalan tersendiri dan menarik untuk ditelaah lebih jauh.

Hoax bertujuan untuk membuat opini publik, menggiring opini publik, membentuk persepsi juga untuk having fun yang menguji kecerdasan dan kecermatan pengguna internet dan media sosial. Tujuan penyebaran hoax beragam tapi pada umumnya hoax disebarkan sebagai bahan lelucon atau sekedar iseng, menjatuhkan pesaing (black campaign), promosi dengan penipuan, ataupun ajakan untuk berbuat amalan-amalan baik yang sebenarnya belum ada dalil yang jelas di dalamnya (Rianto, 2017:61)

Hasil penelitian Ungusari, 2015 (tidak diterbitkan) Bentuk perilaku tidak jujur yaitu meminta jawaban ke teman, mencontek teman, bertanya kepada teman, mengharapkan bantuan teman, ikut menyontek, memanfaatkan kesempatan yang ada, membuka contekan yang sudah disiapkan, berkeinginan untuk menyontek, mencari kesempatan, serta beralasan ke kamar mandi. Tujuan dari perilaku tidak jujur yaitu agar dapat mengerjakan ujian, mendapat nilai yang lebih baik, tetap dapat menjawab walaupun salah, tidak dimarahi guru, karena tidak memiliki jalan lain, membahagiakan orangtua jika mendapatkan nilai bagus, memanfaatkan kesempatan yang ada, tidak memiliki pilihan lain selain menyontek, agar contekan yang dibuat tidak sia-sia, dapat mengingat dan mengisi jawaban, tidak terdapat banyak kesalahan, dan dilakukan dengan alasan kurang belajar, kurang cerdas, sulit mengerjakan soal, dan terpaksa.

Persoalan lainnya banyak sekolah yang kurang memperhatikan perkembangan perilaku siswa terkait kejujuran akademik, contek menyontek saat ujian, konsisten dengan apa yang dikatakan, tanggung jawab terhadap tugas, dan membangun relasi dengan teman. Oleh karena itu Kementrian Agama selaku instansi pemerintah yang bertugas sebagai penyelenggara Pendidikan agama di sekolah perlu melakukan suatu pendalaman standar penyusunan integritas siswa di sekolah.

Konsep Sistem Integritas Nasional, untuk mencari solusi terbaik baik dalam mencegah dan memberantas korupsi, Sistem Integritas Nasional adalah sistem yang berlaku secara nasional dalam rangka pemberantasan korupsi secara terintegrasi yang melibatkan semua pilar penting bangsa (Rahadian, 2014:1)

Pada penelitian ini, selain integritas akademik yang ditelusuri, dua hal lainnya yang juga menjadi variabel adalah tentang toleransi keagamaan dan rasa kebangsaan peserta didik, persoalan pertama tentang sikap dan perilaku peserta didik di sekolah yang berkaitan dengan kerukunan antar umat beragama sedangkan yang kedua hubungannya dengan sikap dan perilaku peserta didik yang berhubungan dengan rasa cinta tanah air dalam bingkai Negara Kesatuan Republik Indonesia (NKRI).

Kerukunan keagamaan di kalangan peserta didik juga telah menjadi perhatian pemerintah saat ini. Pengembangan kerukunan hidup beragama menjadi suatu syarat utama untuk tercapainya kehidupan yang di citacitakan, termasuk di sekolah, karenanya ada beberapa sekolah di nusantara ini peserta didiknya menganut agama yang berbeda. Oleh karena itu, kerukunan hidup beragama harus ditanamkan dan dibangun oleh segenap masyarakat tak terkecuali di lingkungan sekolah, sekolah harus menjadi bagian penting pendidikan tentang kerukunan, sekolah diharapkan mampu mendedikasikan peserta didiknya sebagai penggerak kerukunan antar umat beragama di sekolah, inilah pentingnya penelitian ini dilakukan.

Pengembangan kerukunan di sekolah merupakan hal yang sangat penting, terutama bila ingin menghasilkan pribadi-pribadi yang bertoleransi dan menghargai pemeluk agama lainnya. Pengembangan kerukunan antar umat beragama di kalangan peserta didik ini menjadi tugas bersama seluruh warga sekolah.

Kaitannya dengan cinta tanah air yang menjadi sumber perumusan kebijakan desentralisasi pemerintahan dan pembangunan dalam rangka pengembangan otonomi daerah harus dapat mencegah disintegrasi/pemecahan negara kesatuan, 
serta mencegah rongrongan wibawa pemerintah pusat, mencegah timbulnya pertentangan antara pemerintah pusat dengan pemerintah daerah.

Berdasarkan latar belakang di atas, permasalahan penelitian ini adalah bagaimana realitas integritas peserta didik jenjang pendidikan menengah dalam hal 1) kejujuran akademik, 2) tanggung jawab akademik, 3) toleransi beragama, 4) cinta tanah air serta, 5) faktor-faktor yang memengaruhi integritas peserta didik.

Tujuan penelitian ini adalah untuk mengetahui realitas integritas peserta didik yang berkaitan dengan Tanggung jawab, Kejujuran, Toleransi beragama dan Kecintaan peserta didik terhadap Tanah Air Indonesia. Sedangkan target penelitian ini secara nasional adalah terumuskannya besaran indeks integritas peserta didik pada jenjang pendidikan menengah.

Kejujuran diukur menggunakan tiga komponen yaitu: kesesuaian perkataan dengan perbutan, keberanian menyampaikan kebenaran, dan menghindari kecurangan. Tanggung jawab diukur menggunakan lima komponen yaitu: memiliki inisiatif dalam belajar, mampu menyikapi sendiri permasalahan dengan baik, mematuhi peraturan yang berlaku, melaksanakan kesepakatan bersama, dan menanggung risiko. Toleransi diukur menggunakan dua komponen yaitu: penghargaaan terhadap keberagaman dan berinteraksi dalam keberagaman. Cinta tanah air diukur menggunakan tiga komponen yaitu: mencintai dan bangga terhadap tanah air dan bangsa Indonesia, rela membela negara meskipun sulit, dan perhatian terhadap permasalahan yang ada di lingkungan.

\section{Tinjauan Pustaka}

Kata integritas berasal dari bahasa latin yakni dari kata "Integer" yang berarti "lengkap atau utuh". Jika diartikan dari asal katanya tersebut, menurut Asep Supena (2018) integritas dapat diartikan sebagai suatu usaha yang utuh dan lengkap yang dilandasi dengan kejujuran, kualitas, serta konsistensi karakter dari seseorang tersebut.

Menurut Kamus Besar Bahasa Indonesia, (KBBI) integritas adalah mutu, sifat, dan keadaan yang menggambarkan kesatuan yang utuh, sehingga memiliki potensi dan kemampuan memancarkan kewibawaan dan kejujuran.

Penelitian yang mengkaji integritas peserta didik di lembaga pendidikan sudah cukup banyak dan dapat dijadikan sumber rujukan. Di antaranya yang dilakukan oleh Erlisa Ungusari
(2015) tentang "Kejujuran dan Ketidakjujuran Akademik pada Siswa SMA yang berbasis Agama. Hasil penelitian menunjukkan bahwa tingkat kejujuran dan ketidakjujuran siswa jauh berbeda. Di saat berada pada situasi menghadapi dua ujian sekaligus, perilaku jujur yang muncul sebanyak $86,30 \%$ sedangkan perilaku tidak jujur yang muncul hanya $12,90 \%$. Saat berada pada situasi kesulitan mengerjakan ujian dan melihat teman-teman saling menyontek, perilaku jujur yang muncul sebanyak $41,10 \%$ dan perilaku tidak jujur yang muncul sebanyak 58,90\%. Sedangkan pada situasi belum tuntas belajar dan membuat catatan kecil sebanyak $74,20 \%$ dan perilaku yang muncul hanya $25,80 \%$.

Tinggi rendahnya integritas peserta didik di sebuah sekolah biasanya tidak lepas dari seberapa jauh layanan pendidikan agama dikembangkan. Hasil penelitian Puslitbang Pendidikan Agama dan Keagamaan Badan Litbang dan Diklat tentang Indeks Pendidikan Agama di SMA (Hayadin, 2016) menemukan secara nasional angka layanan Pendidikan Agama sebesar 0,81 (untuk semua agama) di sekolah.

Selanjutnya Menteri Pendidikan dan Kebudayaan, mengeluarkan ketentuan tentang IIUN (Indeks Integritas Ujian Nasionl). di tahun 2017 adanya peningkatan indeks integritas untuk SMA dan sederajat, dari 64,05 pada tahun 2016 menjadi 67,44, di tahun 2017. Data ini memang menunjukkan adanya perubahan perilaku siswa pada saat ujian.

Selama ini penelitian tentang integritas akademik banyak dilakukan hanya mengukur segi kejujuran dalam mengikuti ujian dan belum dikembangkan ke segi lain. Tahun 2017 Puslitbang pendidikan agama dan Keagamaan telah melakukan survei integritas peserta didik. Sebagaimana yang dituliskan oleh Farida Hanum (2017) Kegiatan itu dilakukan kepada 3026 siswa SMA yang tersebar di 120 SMA pada 30 kabupaten/kota di 10 provinsi. Ada lima dimensi yang diukur, yaitu: Kejujuran, Tanggung Jawab, percaya diri, keadilan, dan menjaga kehormatan. Indeks integritas peserta didik di daerah-daerah tersebut sebesar 78,02. Indeks Integritas peserta didik merupakan komposit dari variabel kejujuran $(89,4)$, percaya diri $(84,5)$, tanggung jawab $(83)$, keadilan $(77,9)$, dan menjaga kehormatan $(55,2)$. Selain itu diteliti juga faktorfaktor yang mempengaruhi integritas peserta didik di antaranya sistem akademik, lingkungan sekolah dan lingkungan rumah. 


\section{Definisi Konseptual Integritas}

Kejujuran adalah sejati dengan diri sendiri dan orang lain tentang niat dan kapasitas seseorang. Ini termasuk mengatakan yang sebenarnya dan menyatakan niat seseorang. Termanifestasi dalam komunikasi yang transparan dan terbuka dan berbagi informasi secara proaktif (Barnard, Schurink \& Beer, 2008:43). Kejujuran berkaitan dengan kebenaran sebagai suatu nilai. Ini meliputi tindakan mendengar, bernalar dan berbicara semua tindakan manusia. Sederhananya, kejujuran adalah menyatakan fakta dan pandangan terbenar yang diyakini seseorang. Kejujuran meliputi kejujuran terhadap diri sendiri dan kejujuran terhadap orang lain serta berkaitan dengan motif dan realitas batin sendiri. Secara sederhana dapat dikatakan bahwa kejujuran adalah ketulusan atau keikhlasan (The International Center for Academic Integrity, 2005). Jujur adalah perilaku yang didasarkan pada upaya menjadikan dirinya sebagai orang yang selalu dapat dipercaya dalam perkataan, tindakan, dan pekerjaan (Kementerian Pendidikan Nasional, 2011). Variabelnya kesesuaian perkataan dengan perbuatan, Keberaniaan menyampaikan kebenaran dan menghindari kecurangan

Tanggung jawab, adalah penerimaan tanggung jawab untuk tujuan dan aspirasi seseorang, untuk keterbatasan seseorang dan kekuatan, untuk pilihan yang satu membuat dan konsekuensi dari tindakan seseorang. Penerimaan tanggung jawab orang lain atau lembaga, untuk kepentingan mereka dan untuk peran seseorang dalam keterkaitan satu dengan mereka (Barnard, Schurink \& Beer, 2008:44). Variabelnya memiliki inisiatif dalam belajar, mampu menyikapi sendiri permasalahan dengan baik, Mematuhi peraturan yang berlaku, melaksanakan kesepakatan bersama, menanggung resiko

Toleransi adalah kesediaan untuk menghargai, menerima, atau menghormati segala sesuatu yang ditolak atau ditentang oleh seseorang (Saiful Muzani, 2007). Toleransi adalah sikap dan tindakan yang menghargai perbedaan agama, suku, etnis, pendapat, sikap, dan tindakan orang lain yang berbeda dari dirinya (Kementerian Pendidikan Nasional, 2011). Variabelnya penghargaan terhadap keberagaman, berinteraksi dalam keberagaman

Cinta tanah air, adalah cara berpikir, bertindak, dan berwawasan yang menempatkan kepentingan bangsa dan negara di atas kepentingan diri dan kelompoknya (Kementerian Pendidikan Nasional, 2011). Wibowo menjelaskan cinta tanah air adalah cara berpikir, bersikap, dan berbuat yang menunjukkan kesetiaan, kepedulian dan penghargaan yang tinggi terhadap bahasa dan lingkungan (Wibowo, 2012:63) Menurut Mustari, cinta tanah air adalah cara berpikir, bersikap dan berbuat yang menujukkan kesetiaan, kepedulian dan penghargaan yang tinggi terhadap bahasa, lingkungan fisik, sosial, budaya, ekonomi dan politik bangsa (Mustari, 2011:49) Variabelnya bangga terhadap tanah air dan bangsa Indonesia, rela membela negara meskpiun sulit, perhatian terhadap permasalahan yang ada di lingkungan

Dapat disimpulkan bahwa integritas adalah soal tentang kualitas diri positif yang dimiliki seseorang yaitu berkata dan bersikap jujur, dapat dipercaya dan tidak pernah ingkar janji. Hal ini amat penting dan menjadi modal besar di dalam membangun hubungan yang positif dan saling menguatkan di antara para pemimpin bangsa ini dan masyarakatnya.

\section{Dimensi Integritas Personal}

Hasil penelitian Nisa dkk (2016:35) menunjukkan integritas personal memiliki 9 dimensi yakni: (1) honesty (kejujuran), (2) keeping promise (menepatijanji), (3) loyality (loyalitas), (4) responsibility (tanggung jawab), (5) persistence (persistensi), (6) kindness and caring (ramah dan perhatian), (7) respect (hormat), (8) fairness (keadilan), dan (9) citizenship (kewarganegaraan).

\section{Dimensi Integritas Kebangsaan}

Undang-Undang No 20 Tahun 2003 tentang sistem pendidikan nasional pada pasal 3 menyebutkan bahwa: "Pendidikan nasional berfungsi mengembangkan dan membentuk watak serta peradaban bangsa yang bermartabat dalam rangka mencerdaskan kehidupan bangsa, bertujuan untuk berkembangnya potensi peserta didik agar menjadi manusia yang beriman dan bertakwa kepada Tuhan Yang Maha Esa, berakhlak mulia, sehat, berilmu, cakap, kreatif, mandiri, dan menjadi warga negara yang demokratis serta bertanggung jawab (Furqon, 2010).

Kementerian Pendidikan Nasional (2011) menjelaskan ada 18 nilai-nilai dalam pengembangan pendidikan budaya dan karakter bangsayang dibuat oleh Kemendikbud. (1) religius, (2) jujur, (3) toleransi, (4) disiplin, (5) kerja keras, (6)kreatif, (7) mandiri, (8) demokratis, (9) rasa ingin tahu, (10) semangat kebangsaan; (11) cinta tanah air, (12) menghargai prestasi; (13) bersahabat/komunikatif, (14) cinta damai, 
(15) gemar membaca, (16) peduli lingkungan (17) peduli sosial, (18) tanggung jawab.

Selanjutnya pada sembilan agenda prioritas presiden (program Nawacita) pada butir 8 menjelaskan melakukan revolusi karakter bangsa melalui kebijakan penataan kembali kurikulum pendidikan nasional dengan mengedepankan aspek pendidikan kewarganegaraan, yang menempatkan secara proporsional aspek Pendidikan.

Peraturan Bersama Menteri Agama dan Menteri Dalam Negeri Nomor 9 Tahun 2006, yaitu: keadaan hubungan sesama umat beragama yang dilandasi toleransi, saling pengertian, saling menghormati, menghargai kesetaraan dalam pengamalan ajaran agamanya dan kerjasama dalam kehidupan bermasyarakat, berbangsa dan bernegara di dalam Negara Kesatuan Republik Indonesia berdasarkan Pancasila dan Undang-Undang Dasar Negara Republik Indonesia Tahun 1945.

Artinya keberhasilan pembangunan kerukunan umat beragama di Indonesia dapat dinilai dengan melihat salah satu indikatornya yakni adanya toleransi antar umat beragama. Bagi rakyat Indonesia nilai penting sikap toleran yakni sebagai satu sikap yang sangat penting untuk dimiliki setiap warga negara demi terwujudnya kerukunan umat beragama. Sebaliknya, tidak toleran (intolerant) merupakan satu sikap yang harus dijauhi karena dapat menimbulkan ketegangan, gesekan, bahkan konflik antar umat beragama.

Menurut Mustari (2011:52), yang menjadi indikasi bahwa ciri-ciri mejadi nasionalisme di antaranya: 1) menghargai jasa para tokoh/pahlawan, 2) bersedia menggunakan produk dalam negeri, 3) menghargai keindahan dan budaya Indoensia, 4) hafal lagu-lagu kebangsaan, 5) memilih wisata dalam negeri.

\section{PEMBAHASAN}

\section{Gambaran Umum Maluku Utara}

Provinsi Maluku Utara dengan jumlah penduduknya menurut data statisik 2016 sekitar 1.162.345 jiwa, dengan perbandingan Laki-laki 593.197 jiwa sedangkan perempuan 569.148 jiwa, seolah membawa kita pada kedamaian dan kerahamannya, mengapa demikian, saat penulis balik kepenginapan sekitar pukul dua belas malam, kota Ternate masih nampak keramaian di sepanjang taman-taman dipinggir pantai Ternate tanpa ada rasa gundah. Sepanjang jalan terparkir motor dan konon jarang ada pencurian helm atau kendaraan, aman aman saja tidak ada yg pernah berkelahi. berawal dari inilah tulisan mengenai integritas anak seribu pulau penulis tuliskan.

Keceriaan anak-anak seribu pulau juga asyik menikmati ayunan yang disediakan di taman Nukila, sesekali merekapun menikmati fasilitas taman yang sederhana, berlari, mainan ayunan prosotan, tak ketinggalan penjaja pisang dan kacang goreng oleh 'mama-mama' Maluku sepanjang jalan membuat suasana semakin ceriah

Provinsi Maluku Utara yang dikenal dengan istilah (Moloko Kie Raha), Semboyan: Marimoi Ngone Futuru (Bersatu Kita Teguh) dijuluki: Spice Island. Provinsi Maluku Utara secara administratif memiliki batas wilayah sebagai berikut: Sebelah Timur berbatasan dengan Laut Halmahera; Sebelah Barat berbatasan dengan Laut Maluku; Sebelah Utara berbatasan dengan Samudera Pasifik; dan Sebelah Selatan berbatasan dengan Laut Seram. Hari jadi 4 Oktober 1999 ibu kota provinsi terletak di Sofifi, Total luas $31.982 \mathrm{~km} 2$, terdiri dari 8 Kabupaten dan 2 Kota, jumlah seluruh kecamatan 112 dan 1071 Kelurahan, Penganut Agama di Dominasi Islam sebanyak 991.706 jiwa, kemudian Protestan 337.778 jiwa, Katholik 59,007 jiwa, Hindu 126 jiwa dan Budha 131 jiwa.

Jumlah seluruh sekolah tingkat SMA di Provinsi Maluku Utara yang terdiri dari 8 Kabupaten dan 2 Kota, sebanyak 177 sekolah sedangkan MA sebanyak 66 Madrasah, SMA yang terbanyak di Halmahera Selatan 50 sekolah dan yang paling sedikit berada di Pulau Taliabu hanya 6 sekolah, Angka Partisipasi Murni (APM) di Provinsi maluku Utara pada tingkatan SMA/MA/SMK 63,20 sedangkan Angka Partisipasi Kasar (APK) sebesar 84,81.

Berkaitan dengan penelitian ini khususnya di Provinsi Maluku Utara, peserta didik yang dijadikan responden sebanyak 140 orang yang mewakili 14 SMA dan MA di lima Kabupaten dan Kota (Ternate, Tidore, Hamahera Selatan, Halmahera Timur dan Halmahera Tengah), dari responden tersebut yang diberikan angket laki-laki sebanyak 54 orang dan perempuan 86 orang, dari jumlah tersebut 126 orang beragama Islam dan 14 orang beragama Kristen.

Sekolah yang dimaksud adalah (1) MA Al Munawarah Loleojaya (Halmahera Selatan), (2) MA An-Nur Gandasuli (Halmahera selatan), (3) MAN 1 Weda (Halmahera Tengah), (4) MA Muhammadiyah Soasio (Halmahera Utara), (5) MA Al Khaerat Ternate (Kota Ternate), (6) SMAN 1 Halmahera Selatan, (7) SMAN 7 Halmahera 
Selatan, (8) SMA Al-Khaerat Labuha (Halmahera Selatan), (9) SMAN 1 Halmahera Tengah, (10) SMAN 7 Halmahera Timur, (11) SMA Nurul Hasan (Kota Ternate), (12) SMAN 4 Tidore Kepulauan, (13) SMA Siti Aisiah (Tidore Kepulauan).

\section{Kejujuran (honesty)}

Pengukuran kejujuran pada peserta didik secara sederhana diukur dengan variabel yakni (1) Kesesuaian perkataan dengan perbuatan, (2) Keberaniaan menyampaikan kebenaran dan (3) Menghindari kecurangan. Ketiga hal pokok tersebut diturunkan menjadi sepuluh pertanyaan (Tabel 1 Kejujuran), yang menarik dari isi kuesioner oleh 140 responden, ternyata temuan di lapangan hanya $27 \%$ yang menyatakan berkonsultasi dengan guru BP setiap permasalahan yang mereka hadapi, permasalahannya ketersediaan guru BP yang benarbenar berlatar belakang psikologi kurang tersedia di sekolah para responden.

Temuan yang menarik juga adalah para siswa kurang berani menegur teman yang berperilaku buruk, ini mengindikasikan bahwa hampir sebagian besar responden cenderung acuh tak acuh terhadap teman mereka yang berperilaku buruk, ketika ditanya lebih lanjut, sebagian besar mengatakan bahwa mereka terkadang takut memasuki terlalu jauh hal yang bersifat pribadi (privacy) dari teman mereka, serta takut terlibat langsung hal-hal yang bersifat negatif

Tabel 1 Kejujuran

\begin{tabular}{|c|c|c|c|}
\hline No & INDIKATOR & $\begin{array}{l}\text { JUMLAH } \\
\text { SISWA }\end{array}$ & $\%$ \\
\hline 1 & Konsultasi guru BP & 38 & $27 \%$ \\
\hline 2 & $\begin{array}{l}\text { Membayar makanan sesuai } \\
\text { harga }\end{array}$ & 129 & $92 \%$ \\
\hline 3 & Berkata terus terang & 81 & $58 \%$ \\
\hline 4 & Mengaku salah saat terlambat & 124 & $89 \%$ \\
\hline 5 & $\begin{array}{l}\text { Berani menegur teman ber- } \\
\text { prilaku buruk }\end{array}$ & 14 & $10 \%$ \\
\hline 6 & Mengutip sumber kutipan & 80 & $57 \%$ \\
\hline 7 & Tidak menyontek saat ujian & 51 & $36 \%$ \\
\hline 8 & $\begin{array}{l}\text { Tidak memalsukan tanda } \\
\text { tangan orang tua }\end{array}$ & 114 & $81 \%$ \\
\hline 9 & Mengambil uang dengan izin & 61 & $44 \%$ \\
\hline 10 & $\begin{array}{l}\text { Menggunakan alat tulis teman } \\
\text { dengan izin }\end{array}$ & 75 & $54 \%$ \\
\hline \multicolumn{3}{|c|}{$\begin{array}{l}\text { Rata-Rata Persentasi Pernyataan Positif tentang } \\
\text { kejujuran }\end{array}$} & $55 \%$ \\
\hline
\end{tabular}

Kejujuran saat menyontek masih rendah, hanya $36 \%$, hal ini menunjukkan bahwa responden lebih cenderung pada hasil, artinya mereka masih ada yang berperilaku kurang jujur terutama menyontek pekerjaan temannya saat ujian. Ketika ditanyakan lebih lanjut, mereka sebagian besar mengatakan bahwa teman yang dicontek juga tidak merasa keberatan, bahkan memberikan jawaban dengan senang hati, karena melihat temannya gelisah tidak dapat menyelesaikan soal ujian tersebut, jadi yang perlu mendapat perhatian adalah sikap membantu teman untuk hal yang negatif perlu dihindari.

Secara keseluruhan rata-rata persentasi kejujuran yang ditemukan pada responden masih tinggi 55\%. Namun angkanya pada posisi terendah, Hal ini perlu menjadi perhatian sekolah, mengingat kejujuran ini sangat penting untuk meningkatkan integritas siswa, walaupun survey ini tidak mewakili provinsi Maluku Utara, namun sekolah perlu mempertimbangkan sikap dan perilaku peserta didik dalam hal kejujurannya.

\section{Tanggung jawab (responsibility)}

Dimensi tanggung jawab, variabel-nya (1) Memiliki inisiatif dalam belajar, (2) Mampu menyikapi sendiri permasalahan dengan baik, (3) Mematuhi peraturan yang berlaku, (4) Melaksanakan kesepakatan bersama dan (5) Menanggung resiko.

Tabel 2 Tanggung jawab

\begin{tabular}{|c|c|c|c|}
\hline No & INDIKATOR & $\begin{array}{l}\text { JUMLAH } \\
\text { SISWA }\end{array}$ & $\%$ \\
\hline 1 & $\begin{array}{l}\text { Menegrjakan PR tanpa disu- } \\
\text { ruh }\end{array}$ & 116 & $63 \%$ \\
\hline 2 & Mengulang pelajaran & 66 & $47 \%$ \\
\hline 3 & $\begin{array}{l}\text { Belajar sendiri ketika guru } \\
\text { tidak ada }\end{array}$ & 46 & $33 \%$ \\
\hline 4 & $\begin{array}{l}\text { Membuang sampah semba- } \\
\text { rangan }\end{array}$ & 66 & $47 \%$ \\
\hline 5 & Mencoret saspras sekolah & 74 & $53 \%$ \\
\hline 6 & $\begin{array}{l}\text { menolak ajakan teman karena } \\
\text { belajar }\end{array}$ & 86 & $61 \%$ \\
\hline 7 & Mentaati hasil Musyawarah & 113 & $81 \%$ \\
\hline 8 & $\begin{array}{l}\text { Mengumpulkan tugas tepat } \\
\text { waktu }\end{array}$ & 78 & $56 \%$ \\
\hline 9 & $\begin{array}{l}\text { Mengunjungi teman untuk } \\
\text { belajar bersama }\end{array}$ & 112 & $80 \%$ \\
\hline 10 & $\begin{array}{l}\text { Mengerjakan soal ujian den- } \\
\text { gan jujur meski tidak benar }\end{array}$ & 112 & $80 \%$ \\
\hline $\begin{array}{l}\text { Rata } \\
\text { keju }\end{array}$ & $\begin{array}{l}\text {-Rata Persentasi Pernyataan Positif } \\
\text { uran }\end{array}$ & $\operatorname{tang}$ & $62 \%$ \\
\hline
\end{tabular}


Kelima variabel di atas kemudian dikembangkan menjadi sepuluh pertanyaan sebagaimana pada tabel 2 , ada dua hal yang penting diperhatikan mengenai integritas peserta didik, yang menyangkut tanggung jawab yakni Belajar sendiri saat guru tidak ada, jawaban peserta didik hanya 33\% (rendah) hal ini menunjukkan bahwa sebagian besar responden menyatakan bahwa jika tidak ada guru yang mengajar, mereka juga cenderung tidak belajar sendiri,Demikian halnya dengan perilaku membuang sampah sembarangan dan mengulang pelajaran yang telah diberikan hanya direspon positif oleh 66 responden 47\% (rendah), hal ini menunjukkan bahwa persoalan integritas yang berkaitan dengan tanggung jawab dalam mengembangkan diri dengan belajar secara mandiri masih perlu perhatian sekolah.

Secara keseluruhan rata-rata persentasi tanggapan positif dari responden mengenai integritas peserta didik yang berhubungan dengan tanggung jawab hasilnya Tinggi yakni $62 \%$. Untuk itu jajaran pendidik dan tenaga kependidikan dalam beberapa aspek, perlu mengembangkan kesadaran peserta didik agar bertanggung jawab secara mandiri. Tanggung jawab ini jika tidak dibiasakan akan mengganggu kemajuan perilaku yang baik peserta didik.

\section{Toleransi}

Tabel 3 Toleransi

\begin{tabular}{|c|c|c|c|}
\hline No & INDIKATOR & $\begin{array}{l}\text { JUMLAH } \\
\text { SISWA }\end{array}$ & $\%$ \\
\hline 1 & $\begin{array}{l}\text { Berkeberatan diajar guru yang } \\
\text { berbeda }\end{array}$ & 107 & $76 \%$ \\
\hline 2 & $\begin{array}{l}\text { Menghormati teman yang } \\
\text { melaksanakan ibadah }\end{array}$ & 138 & $99 \%$ \\
\hline 3 & $\begin{array}{l}\text { menghormati teman yang } \\
\text { beda agama }\end{array}$ & 137 & $983 \%$ \\
\hline 4 & $\begin{array}{l}\text { membantu teman beda agama } \\
\text { yang terkena musibah }\end{array}$ & 134 & $96 \%$ \\
\hline 5 & $\begin{array}{l}\text { menyelenggarakan acara } \\
\text { keagamaan di sekolah }\end{array}$ & 108 & $77 \%$ \\
\hline 6 & $\begin{array}{l}\text { menggunakan simbol-simbol } \\
\text { keagamaan di sekolah }\end{array}$ & 98 & $70 \%$ \\
\hline 7 & $\begin{array}{l}\text { menyenangi adat istiadat yang } \\
\text { berbeda suku }\end{array}$ & 100 & $71 \%$ \\
\hline 8 & $\begin{array}{l}\text { tidak keberatan dipimpin oleh } \\
\text { kepsek beda agama }\end{array}$ & 103 & $74 \%$ \\
\hline 9 & $\begin{array}{l}\text { bersedia sekamar dengan te- } \\
\text { man beda agama }\end{array}$ & 108 & $77 \%$ \\
\hline 10 & $\begin{array}{l}\text { Menikmati seni dan adat suku } \\
\text { lain }\end{array}$ & 130 & $93 \%$ \\
\hline
\end{tabular}

Rata-Rata Persentasi Pernyataan Positif tentang $\quad 83 \%$ kejujuran
Dimensi toleransi, diukur dengan variabel (1) Penghargaan terhadap keberagaman dan (2) Berinteraksi dalam keberagaman, kedua variabel ini kemudian dikembangkan dalam sepulu pertanyaan. Berkaitan dengan toleransi, responden di Maluku Utara ditemukan tinggi, artinya ratarata memberikan sikap integritas yang sangat tinggi yakni $83 \%$, hal ini sangat menggembirakan. Dari data table 3 menunjukkan bahwa toleransi keberagaamaan respoden sangat baik, hal in perlu dipertahankan sehingga kedepan, trauma kasus yang berbasis keagamaan yang pernah terjadi di Maluku Utara diharapkan tidak akan terulang, yang tertinggi dari isian kuesioner tersebut adalah Menghormati teman yang melaksanakan ibadah (99\%) menyatakan mereka saling menghargai teman jika ada yang ingin melaksanakan ibadah menurut agama dan keyakinan masing-masing.

\section{Cinta Tanah Air}

Tabel 4 Cinta Tanah Air

\begin{tabular}{|c|c|c|c|}
\hline No & INDIKATOR & $\begin{array}{l}\text { JUMLAH } \\
\text { SISWA }\end{array}$ & $\%$ \\
\hline 1 & $\begin{array}{l}\text { Senang mengunjungi musium } \\
\text { sejarah }\end{array}$ & 130 & $93 \%$ \\
\hline 2 & $\begin{array}{l}\text { Menyanyikan lagu kebang- } \\
\text { saan setiap acara resmi }\end{array}$ & 134 & $96 \%$ \\
\hline 3 & menikmati lagu-lagu daerah & 124 & $89 \%$ \\
\hline 4 & $\begin{array}{l}\text { Suka lagu-lagu nasional yang } \\
\text { menumbuhkan cinta tanah air }\end{array}$ & 140 & $100 \%$ \\
\hline 5 & $\begin{array}{l}\text { Menyenangi produk dalam } \\
\text { negeri }\end{array}$ & 124 & $89 \%$ \\
\hline 6 & $\begin{array}{l}\text { Merasa bangga mengibarkan } \\
\text { bendera merah putih }\end{array}$ & 140 & $100 \%$ \\
\hline 7 & $\begin{array}{l}\text { Senang memajang lambang } \\
\text { negara Indonesia }\end{array}$ & 136 & $97 \%$ \\
\hline 8 & $\begin{array}{l}\text { Melerai jika ada siswa yang } \\
\text { berselisih }\end{array}$ & 103 & $74 \%$ \\
\hline 9 & $\begin{array}{l}\text { Memiliki kewajiban membela } \\
\text { negara berdasarkan Pancasila } \\
\text { dan UUD } 1945\end{array}$ & 135 & $96 \%$ \\
\hline 10 & $\begin{array}{l}\text { Ikut kerja bakti membersih- } \\
\text { kan lingkungan }\end{array}$ & 132 & $94 \%$ \\
\hline
\end{tabular}

Rata-Rata Persentasi Pernyataan Positif tentang

kejujuran

Responden $(\mathrm{N})=140$

Dimensi cinta tanah air, diukur dengan variabel (1) Bangga terhadap tanah air dan bangsa Indonesia, (2) Rela membela negara meskipun sulit 
dan (3) Perhatian terhadap permasalahan yang ada di lingkungan, integitas dari 140 responden pada pernyataan positif mengenai cinta tanah air sebesar 93\% atau sangat tinggi, yang menarik dari variabel tersebut adalah menyanyikan lagu yang menumbuhkan rasa cinta tanah air dan merasa bangga mengibarkan bendera merah putih semua menjawab $100 \%$ setuju.

Sebagaimana pernyataan mengenai Toleransi di atas, maka hasil yang didapatkan untuk mengukur rasa cinta tanah air peserta didik di SMA/MA sebagai responden juga rata-rata persentasinya sangat tinggi $(83 \%)$. Cuma ada yang menjadi perhatian pemerintah yang berkaitan dengan rasa cinta tanah air, sebagian responden terutama yang berada di pulau yang jauh dari ibukota provinsi Maluku Utara adalah simbol-simbol menyangkut kenegaraan (Lambang Burung garuda, bendera merah putih yang dipasang di songkok) jarang diperjualbelikan, hal ini yang dikeluhkan oleh responden.

\section{Pengalaman Agama}

Tabel 5 Pengalaman Agama

\begin{tabular}{clrc}
\hline No & INDIKATOR & $\begin{array}{c}\text { JUMLAH } \\
\text { SISWA }\end{array}$ & $\%$ \\
\hline 1 & $\begin{array}{l}\text { Menyukai mata pelajaran } \\
\text { agama }\end{array}$ & 136 & $97 \%$ \\
2 & $\begin{array}{l}\text { Ada teman penganut agama } \\
\text { lain dilingkungan sekolah }\end{array}$ & 61 & $44 \%$ \\
3 & $\begin{array}{l}\text { Ada rumah ibadah lain diling- } \\
\text { kungan sekolah }\end{array}$ & 10 & $7 \%$ \\
4 & $\begin{array}{l}\text { Ada guru agama yang menga- } \\
\text { nut agama lain di sekolah }\end{array}$ & 59 & $42 \%$ \\
\hline Responden (N) =140 & &
\end{tabular}

Setelah mendapatkan Indikator dari Integritas yang berkaitan dengan Kejujuran, tanggung jawab, Toleransi dan Cinta Tanah Air, maka respondenpun diminta untuk memberikan tanggapan mengenai dukungan lainnya, yang pertama adalah tentang pengalaman Agama responden, Hampir sebagian besar menyatakan menyenangi pelajaran Pendidikan agama (97\%) artinya keberadaan guruguru agama dalam memberikan Pendidikan agama di sekolah sudah cukup baik, walapun untuk point rumah ibadah di sekolah masih sangat kecil, hanya $7 \%$ yang menyatakan ada, hal ini mengindikasikan bahwa pemerintah dan sekolah perlu mengadakan dan menyediakan sarana rumah ibadah di sekolah untuk peserta didik.

\section{Sumber Pengetahuan Agama}

Pada pernyataan ini, ada dua hal yang ditanyakan pada responden, Pertama selain di sekolah, dimana responden belajar Agama, jawabannya $31 \%$ menyatakan belajar di rumah dan $40 \%$ pengetahuan agama yang mereka dapatkan di tempat ibadah, sedangkan responden menyatakan kedua-duanya (rumah ibadah dan di rumah) sebesar $69 \%$, hal ini menggambarkan bahwa responden harus didorong untuk menambah pengetahuan agama selain di sekolah memanfaatkan rumah ibadah, sementara aktifitas di rumah harus lebih ditingkatkan, karena masih rendah pengetahuan agama yang responden terima dari rumah.

Kedua, Saat ditanyakan pada responden tentang materi pengetahuan agama yang mereka terima selain di sekolah yang terbesar menjawab di televisi sekitar $40 \%$ dan media sosial sekitar $29 \%$ selebih Surat kabar dan Radio hanya 3\%.

\section{Sikap dan Perilaku Keagamaan}

Integritas responden yang berkaitan dengan aktifitas mereka dalam kurun waktu enam bulan terakhir yang berkaitan dengan sikap dan perilaku keagamaan, ada lima hal pernyataan responden mengenai hal tersebut dapat kita lihat pada table di bawah ini.

Tabel 6 Sikap dan Perilaku Keagamaan

\begin{tabular}{llllll}
\hline NO & PERNYATAAN & TIDAK PERNAH & JARANG & SERING & SELALU \\
\hline 1 & Berdoa sebelum belajar & $3,6 \%$ & $26,4 \%$ & $22,9 \%$ & $47,1 \%$ \\
2 & Bersedekah di sekolah & $4,3 \%$ & $30 \%$ & $33,6 \%$ & $32,1 \%$ \\
3 & Melakukan Ibadah di sekolah & $37,1 \%$ & $18,7 \%$ & $17,1 \%$ & $27,1 \%$ \\
4 & Membaca kitab suci di sekolah & $29,3 \%$ & $19,3 \%$ & $17,1 \%$ & $34,3 \%$ \\
5 & Mengucapkan salam saat bertemu guru & $5 \%$ & $16,4 \%$ & $30 \%$ & $48,6 \%$ \\
\hline & RATA-RATA & $15,86 \%$ & $22,16 \%$ & $24,14 \%$ & $37,84 \%$ \\
\hline
\end{tabular}

Responden $(\mathrm{N})=140$ 


\section{Kelengkapan Sarana}

Tabel 7 Kelengkapan Sarana

\begin{tabular}{llrr}
\hline No & INDIKATOR & $\begin{array}{c}\text { JUMLAH } \\
\text { SISWA }\end{array}$ & $\%$ \\
\hline 1 & Fasilitas temuan barang hilang & 21 & $15 \%$ \\
2 & $\begin{array}{l}\text { brosur atau pengumuman } \\
\text { larangan menyontek }\end{array}$ & 82 & $59 \%$ \\
3 & $\begin{array}{l}\text { sanksi tegas bagi pelanggar } \\
\text { aturan }\end{array}$ & 125 & $89 \%$ \\
4 & Kegiatan bakti sosial & 135 & $96 \%$ \\
5 & $\begin{array}{l}\text { Guru BK yang mendengarkan } \\
\text { keluhan peserta didik }\end{array}$ & 70 & $50 \%$ \\
6 & $\begin{array}{l}\text { Uang kas untuk membantu } \\
\text { teman yang mengalami kesu- } \\
\text { litan/musibah }\end{array}$ & 123 & $88 \%$ \\
7 & $\begin{array}{l}\text { Kajian atau pembahasan } \\
\text { terkait gender }\end{array}$ & 91 & $65 \%$ \\
8 & $\begin{array}{l}\text { Kajian atau pembahasan } \\
\text { terkait perbadaan agama }\end{array}$ & 89 & $64 \%$ \\
9 & Kantun Kejujuran \\
10 & $\begin{array}{l}\text { Metode pembelajaran PA } \\
\text { sudah bervariasi }\end{array}$ & 41 & $29 \%$ \\
11 & $\begin{array}{l}\text { Tempat Ibadah sudah mema- } \\
\text { dai }\end{array}$ & 711 & $79 \%$ \\
12 & $\begin{array}{l}\text { Perpustakaan sekolah dileng- } \\
\text { kapi buku-buku agama }\end{array}$ & 115 & $82 \%$ \\
13 & $\begin{array}{l}\text { Sekolah memiliki ruang } \\
\text { rohani keagamaan bagi agama } \\
\text { lain }\end{array}$ & 10 & $7 \%$ \\
14 & $\begin{array}{l}\text { Ketersediaan guru agama } \\
\text { sudah memadai }\end{array}$ & 112 & $80 \%$ \\
\hline
\end{tabular}

Rata-Rata Persentasi Pernyataan Positif tentang kejujuran

Responden $(\mathrm{N})=140$

Kelengkapan sarana yang dimaksud dalam survey ini adalah dukungan kelengkapan sarana untuk memberikan pengaruh positif terhadap Pendidikan Agama di sekolah termasuk yang mendukung sikap dan perilaku peserta didik agar berintegritas.

Menurut pandangan responden yang memberikan tanggapan pada kuesioner yang mereka isi secara umum tergolong masih masih tinggi $61 \%$, walaupun harapannya masih kecil, temuan ini karena beberapa faktor, misalkan fasilitas temuan barang hilang hanya $15 \%$ yang menyatakan ada, guru BK masih kurang mendengarkan keluhan peserta didik (hanya 50\%), Kantin kejujuran yang dulunya dipopularkan sekarang hanya $29 \%$ yang menyatakan ada. Yang perlu mendapatkan perhatian adalah perlunya ruang rohani bagi agama lain jika memang memenuhi persyaratan siswa, karena hanya $10 \%$ yang menyatakan bahwa sekolah menyiapkan tempat ibadah agama minoritas di tempat responden bersekolah.

\section{Lingkungan Keluarga}

\begin{tabular}{llrl}
\multicolumn{3}{c}{ Tabel 8 Lingkungan Keluarga } \\
\hline No & $\begin{array}{l}\text { INDIKATOR } \\
\text { JUMLAH } \\
\text { SISWA }\end{array}$ & $\%$ \\
\hline 1 & $\begin{array}{l}\text { Sembahyang jamaah dirumah } \\
\text { minimal sekali seminggu }\end{array}$ & 57 & $41 \%$ \\
2 & $\begin{array}{l}\text { membaca kitab suci minimal } \\
\text { seminggu sekali }\end{array}$ & 98 & $70 \%$ \\
3 & $\begin{array}{l}\text { Sharing/diskusi dengan kelu- } \\
\text { arga minimal seminggu sekali }\end{array}$ & 113 & $81 \%$ \\
4 & $\begin{array}{l}\text { Pembagian tugas menjaga } \\
\text { kebersihan rumah }\end{array}$ & 114 & $81 \%$ \\
5 & $\begin{array}{l}\text { Sanksi tegas bagi pelanggar } \\
\text { aturan keluarga }\end{array}$ & 98 & $70 \%$ \\
6 & $\begin{array}{l}\text { Kegiatan tamasya keluarga } \\
\text { Belajar bersama dengan orang } \\
\text { tua atau saudara }\end{array}$ & 99 & $71 \%$ \\
8 & Kebiasaan menabung & $80 \%$ \\
\hline $\begin{array}{l}\text { Rata-Rata Persentasi Pernyataan Positif tentang } \\
\text { kejujuran }\end{array}$ & 70 & $50 \%$ \\
\hline Responden (N) = 140 & $68 \%$ \\
\hline
\end{tabular}

Dukungan keluarga menjadi hal yang sangat penting untuk membangun integritas peserta didik, tanggapan responden mengenai hal tersebut memang masih perlu mendapatkan perhatian yang besar, karena rata-rata persentasi yang didapatkan sekitar 68\% (tinggi), dari temuan tersebut beberapa responden masih kurang melakukan ibadah secara bersama di rumah (41\%), termasuk kebiasaan menabung hanya $50 \%$ sedangkan yang lainnya masih cukup tinggi.

\section{Lingkungan Tempat Tinggal}

Selain lingkungan keluarga di atas, jika kita ingin mengukur integritas peserta didik, maka faktor lain yang tidak dapat dinafikkan adalah faktor lingkungan tempat tinggal, pengaruh lingkungan dalam beberapa hasil penelitian menujukkan cukup besar memberikan kontribusi perubahan pada perilaku dan sikap seseorang. 
Tabel 9 Lingkungan Tempat Tinggal

\begin{tabular}{llrl}
\hline No & INDIKATOR & $\begin{array}{c}\text { JUMLAH } \\
\text { SISWA }\end{array}$ & $\%$ \\
\hline 1 & $\begin{array}{l}\text { Keberadaan rumah ibadah } \\
\text { dilingkungan temat tinggal }\end{array}$ & 133 & $95 \%$ \\
2 & $\begin{array}{l}\text { Kegiatan bakti sosial yang } \\
\text { melibatkan remaja }\end{array}$ & 121 & $86 \%$ \\
3 & $\begin{array}{l}\text { Kegiatan karang taruna } \\
4\end{array}$ & 37 & $26 \%$ \\
& $\begin{array}{l}\text { Kegiatan Kerohanian diling- } \\
\text { kungan }\end{array}$ & 85 & $61 \%$ \\
5 & $\begin{array}{l}\text { Perayaan hari-hari besar aga- } \\
\text { ma yang melibatkan remaja }\end{array}$ & 121 & $86 \%$ \\
6 & $\begin{array}{l}\text { Perayaan hari besar nasional } \\
7\end{array}$ & 126 & $90 \%$ \\
Perlombaan kejuaraan antar & 94 & $67 \%$ \\
\hline $\begin{array}{l}\text { Rata-Rata Persentasi Pernyataan Positif tentang } \\
\text { kejujuran }\end{array}$ & & $73 \%$ \\
\hline Responden (N) = 140
\end{tabular}

Dalam survei ini juga, responden diminta untuk memberikan tanggapan mengenai dukungan lingkungan sekitar dalam mengembangkan integritas mereka (peserta didik), tentu saja hasil survei ini masih relatif dini jika pengaruh tersebut secara general di Maluku Utara, namun setidaknya ada informasi awal mengenai dukungan lingkungan sekitar. Dari hasil survei responden menyatakan bahwa hasilnya rata-rata masih tinggi (73\%), walaupun untuk kegiatan karang taruna yang melibatkan peserta didik tingkat SMA/MA masih sangat sedikit (26\%), sementara lainnya sudah menujukkan dukungan yang tinggi.

\section{Gabungan Hasil indikator Integritas dan Faktor Pendukung}

Selain lingkungan keluarga di atas, jika kita ingin mengukur integritas peserta didik, maka faktor lain yang tidak dapat dinafikkan adalah faktor non teknis, terutama hal-hal yang tidak masuk dalam materi kuesioner.

\begin{tabular}{lll}
\hline No & INDIKATOR & $\%$ \\
\hline 1 & Kejujuran & $55 \%$ \\
2 & Tanggung jawab & $62 \%$ \\
3 & Toleransi & $83 \%$ \\
4 & Cinta tanah air & $93 \%$ \\
\hline Rata-Rata & $73 \%$ \\
\hline
\end{tabular}

Survei mengenai integritas peserta didik yang dilakukan di Maluku Utara ini, tentu saja masih banyak kekurangan dan perlu dilakukan penelitian lebih lanjut, beberapa alasannya karena responden belum mewakili provinsi namun data ini sangat berpengaruh jika diambil sampel secara nasional, selain itu kondisi psikologi responden saat mengisi kuesioner masih diabaikan, sehingga dalam survei ini diasumsikan bahwa peserta didik dari SMA/MA pernyataannya dianggap benar pada saat mereka mengisi beberapa item pertanyaan dalam angket, termasuk jumlah peserta didik yang di mewakili setiap sekolah diambil secara acak sebanyak 10 peserta didik

Terlepas dari kelemahan dari penelitian survei ini, peneliti ingin menyampaikan bahwa banyak hal temuan-temuan yang menarik dan perlu di teliti lebih lanjut dalam bentuk penelitian kualitatif, sehingga persoalan integritas yang berkaitan dengan kejujuran, tanggung jawab dapat lebih mendalam, termasuk perilaku peserta didik menanggapi toleransi keberagamaan di sekolah dan cinta tanah air. Dari data survei mengenai integritas responden ditemukan bahwa rata-rata persentasi yang didapatkan sebesar 73\% (tinggi), hal ini perlu diapresiasi, walaupun dari data tersebut tingkat kejujuran dan tanggung jawab responden masih rendah, keempat indikator tersebut di atas, tidak menyatakan gabungan, artinya masing-masing indikator integitas berdiri sendiri, sehingga jika dijumlahkan tidak mendapatkan hasil 100\%, maka peneliti hanya memberikan gambaran rata-rata dari hasil angket masing-masing responden yang berjumlah 140 peserta didik.

Khusus mengenai kejujuran dan tanggung jawab walaupun hasilnya rendah, pandangan pribadi peneliti setidaknya secara psikologi, mereka mampu menjawab secara jujur pernyataanpernyataan yang dituliskan dalam angket, artinya secara angket mungkin hasilnya rendah, namun secara integritas harus diapresiasi secara positif karena mereka mampu menyatakan secara terbuka tentang kelemahan-kelemahan responden miliki.

Selain temuan-temuan di atas yang secara kuantitatif menghasilkan angka persentasi, peneliti juga dapat memberikan gambaran bahwa kondisi social budaya di maluku Utara cukup berpengaruh, walaupun dalam penelitian ini tidak menjadi bagian yang di survey. Sebagai contoh budaya kesultanan ternate, Tidore, Bacan dan Jailolo juga sangat mempengaruhi rasa toleransi dan Cinta tanah air, sehingga wajar dalam survei ini hasil yang didapatkan persentasinya cukup tinggi.

Peta geografis masing-masing sekolah tempat responden menerima ilmu juga mempengaruhi survey ini, karena jarak antara sekolah dan lingkungan rumah responden tergolong jauh, 
sehingga informasi negative mengenai isu kerukunan keagamaan cenderung kecil terjadinya perselisihan yang berdampak negative terhadap kerukunan antara peserta didik.

Sebagai bagian akhir dari pembahasan ini, peneliti ingin menyampaikan ucapan terima kasih kepada seluruh pembantu lapangan saudara Rakhmat, Iqbal, Hidayat, Muhammar Amir, Hasan termasuk teman-teman anggota GP Ansor Kota Ternate, seluruh kepala sekolah dan Kepala MA yang dijadikan sampel dalam penelitian ini, Kepala Kantor kementerian Agama dan Dinas Pendidikan se Provinsi Maluku Utara, semoga segala bantuannya dapat memberikan manfaat untuk pengembangkan nilai-nilai integritas di kalangan peserta didik di Maluku Utara di masa mendatang.

\section{PENUTUP}

\section{Kesimpulan}

Pengukuran kejujuran pada peserta didik secara sederhana diukur dengan variabel yakni (1) Kesesuaian perkataan dengan perbuatan, (2) Keberaniaan menyampaikan kebenaran dan (3) Menghindari kecurangan, Secara keseluruhan ratarata persentasi kejujuran yang ditemukan pada responden Tinggi yakni 55\%. Walalupun harapan angka tersebut masih minimal.

Dimensi tanggung jawab, diukur dengan variabel (1) Memiliki inisiatif dalam belajar, (2) Mampu menyikapi sendiri permasalahan dengan baik, (3) Mematuhi peraturan yang berlaku, (4) Melaksanakan kesepakatan bersama dan (5) Menanggung resiko. Secara keseluruhan ratarata persentasi tanggapan positif dari responden mengenai integritas peserta didik yang berhubungan dengan tanggung jawab hasilnya juga tinggi yakni $62 \%$, namun sama halnya dengan kejujuran angka harapannya masih minimal.

Dimensi toleransi, diukur dengan variabel (1) Penghargaan terhadap keberagaman dan (2) Berinteraksi dalam keberagaman, kedua variabel ini kemudian dikembangkan dalam sepulu pertanyaan. Berkaitan dengan toleransi, responden di Maluku Utara ditemukan tinggi, artinya ratarata memberikan sikap integitas yang Sangat tinggi yakni $83 \%$.

Dimensi cinta tanah air, diukur dengan variabel (1) Bangga terhadap tanah air dan bangsa Indonesia, (2) Rela membela negara meskpiun sulit dan (3) Perhatian terhadap permasalahan yang ada di lingkungan, integitas dari 140 responden pada pernyataan positif mengenai cinta tanah air sebesar $93 \%$ atau sangat tinggi.
Faktor pendukung integritas peserta didik dalam survei ini sudah cukup baik, sekolah sudah mampu memberikan ruang sebesar-besarnya bagi peserta didik untuk mengembangkan integritasnya secara mandiri.

\section{UCAPAN TERIMA KASIH}

Artikel yang hadir di hadapan pembaca budiman ini, tak lepas dari kontribusi beberapa pihak, yang sejatinya mendapat apresiasi dari penulis. Teriring ucapan terima masih pada Kepala Balai Litbang Agama Makassar, pengelola Jurnal alQalam, dan kalangan responden yang dengan rela membagi data/informasi sehingga lahir artikel ini.

\section{DAFTAR PUSTAKA}

Atjo, Rusli Andi. 2009. Orang ternate dan kebudayaannya. Jakarta: Cikoro Trirasundar.

Barnard, A,. Schurink, W,. De Beer, M. (2008). A conceptual framework of integrity.Journal of Industrial Psychology. 34 (2), 40 - 49. diunduh 16 Maret 2018

Barnard, Schurink\& Beer, 2008, A Conceptual Framework of Integrity, Vol 34 No.2 PP 40 49

Farida Hanun. 2017. Laporan Penelitian Indeks Integritas Siswa di Sekolah. Jakarta: Puslitbang Pendidikan Agama dan Keagamaan Badan Litbang dan Diklat Kementerian Agama.

Hayadin. 2016. Indeks Pendidikan Agama di SMA. Puslitbang Pendidikan Agama dan Keagamaan Badan Litbang dan Diklat.

Jones, L. R. 2011. Academic Integrity \& Academic Dishonesty: A Handbook About Cheating \& Plagiarism (Revised \& Expanded Edition). Melbourne, Florida: Florida Institute of Technology

Kementrian Pendidikan Nasional. 2011. Panduan Pelaksanaan Pendidikan Karakter. Jakarta: Badan Penelitian dan Pengembangan, Pusat Kurikulum dan Perbukuan, h.6

M. Furqon Hidayatullah.2010.Guru Sejati: Membangun Insan BerkarakterKuat dan Cerdas. Surakarta: Yuma Pustaka, h. 12

Supena, Asep. 2018. Makalah Survei integritas Siswa yang disampaikan di Puslitbang Pendidikan Agama dan Keagamaan tanggal 26 Januari 2018

Mustari,M. 2011, Nilai Karakter.Yogyakarta: LaksBang

Nisa, dkk, 2016. Indeks Integritas Personal, UIN Jakarta, h. 35 
Paul Suparno, S.J. Integritas Pendidikan: Sekolah, Guru, dan Siswa. Ursula, Tangerang

Peraturan Bersama Menteri Agama dan Menteri Dalam Negeri Nomor 9 dan 8 Tahun 2006, tentang Pedoman Pelaksanaan Tugas Kepala Daerah dalam Pemeliharaan Kerukunan Umat Beragama, Pemberdayaan Forum Kerukunan Umat Beragama, dan Pendirian Rumah Ibadat, Bab I, pasal 1, ayat 1. Dalam Negeri Nomor 9 Tahun 2006/ Nomor 8 Tahun 2006, hal.10.

Rahadian, Sistem Integritas nasional Sebagai Kebijakan mencegah dan Memberantas Korupsi di Indonesia, Prosiding Seminar STIAMI, Volume 1 Nomor 2 Oktober 2014 hal. 1-11

Rianto Rahadi, Dedi, Perilaku Pengguna dan Informasi Hoax di Media Sosial, Jurnal
Manajemen dan Kewirausahaan Vol 5 no. 1 Tahun 2017 Hal. 58-70

The Center for Academic Integrity. 1999. The fundamental values of academic integrity. Durham North Carolina: Duke University.

Ungusari, E. 2015. Kejujuran dan Ketidakjujuran Pada Siswa SMA Berbasis Agama. Surakarta: Fakultas Psikologi Universitas Muhammadiyah

www.kemendikbud.go.id, 2016, 2017 diunduh 12 Januari 2018

http:/ //kkbi.web.id/ integritas diunduh 12 Januari 2018

http://pengertiandefinisi.com/pengertianintegritas-menurut-pandangan-para-ahli/

https://catatan98.wordpress.com/2012/11/18/ membangun-integritas-bangsa-dan-jiwa nasionalisme/ diunduh 12 Januari 2018 